\title{
PDPN Gene
}

National Cancer Institute

\section{Source}

National Cancer Institute. PDPN Gene. NCI Thesaurus. Code C104785.

This gene plays a role in cell shape. 